\title{
The Effect of Sales and Operating Costs on Net Income of Halal Award-Winning Companies in Indonesia Stock Exchange
}

\author{
R. Aditya Kristamtomo Putra, Nana Diana*, Wirman, M. Nasim Harahap \\ Faculty of Economics, Universitas Singaperbangsa Karawang, Karawang, Indonesia
}

Received March 17, 2021; Revised May 13, 2021; Accepted June 6, 2021

\section{Cite This Paper in the following Citation Styles}

(a): [1] R. Aditya Kristamtomo Putra, Nana Diana, Wirman, M. Nasim Harahap, "The Effect of Sales and Operating Costs on Net Income of Halal Award-Winning Companies in Indonesia Stock Exchange," Universal Journal of Accounting and Finance, Vol. 9, No. 3, pp. 383 - 387, 2021. DOI: 10.13189/ujaf.2021.090312.

(b): R. Aditya Kristamtomo Putra, Nana Diana, Wirman, M. Nasim Harahap (2021). The Effect of Sales and Operating Costs on Net Income of Halal Award-Winning Companies in Indonesia Stock Exchange. Universal Journal of Accounting and Finance, 9(3), 383 - 387. DOI: 10.13189/ujaf.2021.090312.

Copyright $@ 2021$ by authors, all rights reserved. Authors agree that this article remains permanently open access under the terms of the Creative Commons Attribution License 4.0 International License

\begin{abstract}
The effect of sales (X1) and operational cost (X2) variables on net profit (Y) on the 2019 LPPOM MUI Halal Award Winner Companies is Listed on the Indonesia Stock Exchange. The method used is descriptive statistics with a quantitative approach. A classic assumption test is also utilized to analyze the data and multiple linear regression analysis to determine the level of relationship or influence given by the sales and operating costs to net income. The data used are the secondary data with quantitative types of data for the period 2014-2018 with the population of this study being the company that won the 2019 Halal Award listed on the Indonesia Stock Exchange. The sampling method is purposive sampling method with the number of observations of 6 companies. The results of the study showed that sales and operating costs variables simultaneously affect net income. However, partial testing showed that sales have no effect on net income and operational costs partially affect net income. The results of the coefficient of determination indicate that net income $(\mathrm{Y})$ is influenced by sales (X1) and operating costs (X2) as much as $90.1 \%$ and the rest is left influenced by other variables by $9.9 \%$.
\end{abstract}

Keywords Sales, Operational Costs, Net Profit, Halal Producers

\section{Introduction}

To maintain the continuity of life, people need a lot of needs. Needs can be defined as a feeling of deficiency to the satisfaction of certain basic. Needs can be divided into two, namely the physical needs and spiritual needs. Human needs in need of clothing, food and shelter or a place to stay. To meet these needs humans to require and consume goods and services. In economics, the activities are carried out by human consumption in order to reduce or spend some value or benefit of goods and services. To consume a product, cannot arbitrarily do because we do not know exactly the content of what is contained in the product. Therefore, man as a consumer should intelligently choose and find out what you want to eat, especially for food. Consumers are not only demanding the safety of products, but also quality and nutrients contained within it. For Muslim consumers, food products are safe not just free from the threat of physical, chemical and microbiological, but also there is an element that is essential, that is safe from danger, prohibited or questionable [1, 2]. The concept of halal products in the life of Muslim communities in Indonesia has been applied in public life as an early indicator of a determinant of halal food to be consumed by the Muslim community in Indonesia. Halal destined for something good and cleans to be eaten or consumed by humans according to Islamic Shari'a. The halal or not a food safety consideration are fundamental to Muslims [1, 3]. Muslim 
consumers tend to choose products that have been declared lawful than the products that have not been declared lawful by the relevant authorities.

In this regard, as one of main producer of halal products, companies have the responsibility to provide halal product. In terms of financial performance, sales are an important aspect for the company to maintain the viability of the halal manufacturing companies. The sale of products is major revenue to finance the operations of the company. To manage the sales of which covers all activities of the company to facilitate management in controlling the activities of the company $[6,7]$. Moreover, the net profit derived from the transaction revenue, expenses, gains, and loses is summarized in the income statement. Profit is derived from the difference between the input pour source (revenue and profit) with the resources out (expenses and losses) [8]. Sales and costs are empirically supposed to have a significant effect on net income, increased sales, and cost efficient, it should affect the increase in profits from the company and vice versa [9, 10, 11]. Murhadi [12] defines operating costs as sorts related to the company's operations and administration, advertising cost, depreciation costs, as well as repair and maintenance. The main purpose of the company's operations is in fact achieving the maximum net profit.

Susilawati \& Mulyana [13] show that sales and operating costs simultaneously affect the net profit, and partially sales and operating costs are also an effect on net income. It is also in line with Hernalis [14] showing that partially net sales and operating costs have a significant effect on net income and simultaneously, net sales and operating costs have a significant effect on net income. However, it is contrary to Ferliyanti [15] showing that partially sales and production cost effect on net income, while operating costs have no effect on net income.

\section{Research Methods}

The quantitative research while the source of data in this study using secondary data in the form of the company's annual financial report the winners of the top brand LPPOM MUI halal is listed in Indonesia Stock Exchange by the end of the financial year on December 31, 2014 to 2018. The source of data is obtained from website.

Based on data from Global religious future, Indonesia's population is Muslim in 2010 reached 209.12 million or approximately $87 \%$ of the total population. Then in 2020 , the Muslim population of Indonesia is expected to reach 229.62 million. A large number of Muslim populations make halal products become the main condition for consuming a product. Indonesia has a competent institution to guarantee the halla product, the MUI (Indonesian Uleme Council) [1, 2]. in his study, aided by LPPOM MUI MUI (Institute for Food, Drugs, and Cosmetics Indonesia Uleme Council). The agency was created to assist the Indonesian Ulema Council in determining the wisdom, formulate rule, recommendation and guidance related to food, drugs and cosmetic in accordance with the teachings of Islam. In other words, LPPOM-MUI was established to provide a sense of peace to the people about the products they consume. This authority authorized of products made by LPPOM-MUI. Only product that has been certified by the MUI pitch can be labeled halal in every product.

Although these companies have been instrumental in strengthening the halal market, no doubt these companies will seek profit at its core. Profit is an indicator of success for the company profit-oriented, because the success of a company is usually seen from the amount of income earned in a particular period. Profit is the excess of revenues over the load in connection with business activities. The net profit is the excess of all revenue and profit of all the loads and losses and the net increase of the capital. In order to obtain profit in accordance with the desired, companies need to prepare a good profit planning. It is determined by the company's ability to predict business conditions in the future, full of uncertainty, and observe the possible factors that could affect earnings $[4,5]$.

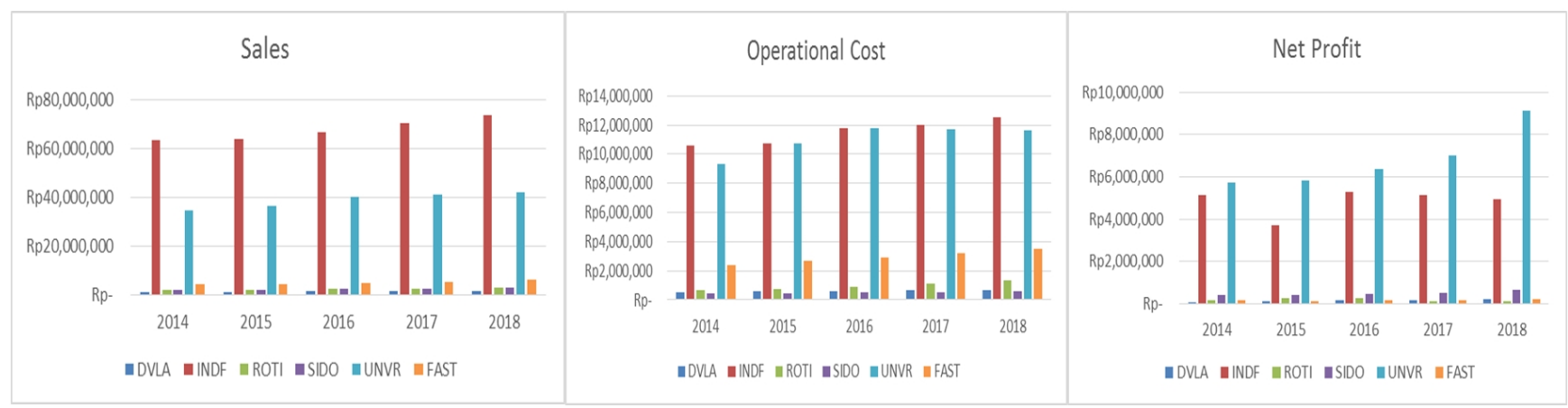

Figure 1. Sales, Operational Cost and Net Profit of Halal Award-Winning Companies 
Figure 1 showed that PT. Darya-Varia Laboratoria TBK, PT. Indofood Sukses Makmur Tbk, PT. Medicinal and Pharmaceutical Industry Sido Appears Tbk, and PT. Unilever Indonesia Tbk have increased earnings from 2014 until 2018. PT. Nippon Insosari Corpindo Tbk experience increase in profit from 2014 until 2016, but in 2017 up to the year 2018 net income declined. Ehile PT. Fast Food Indonesia Tbk fluctuations in net income for 2014 until 2018. the figure showed that an increase in sales of the company's award LPPOM MUI Halal Award every year. The highest sales profits will not be separated from sales and costs, including operating costs. The figure also showed that operating costs in the company's awards-runing LPPOM MUI halal 2019 also increased the period 2014-2018, the highest costs on PT Indofood Sukses Makmur Tbk, while the lowest operational costs seen in PT. Medicinal and Pharmaceutical Industry Sido Appears Tbk.

\section{Result and Discussion}

Calculation to calculate the linear regression analysis is supported by SPSS 23, which obtained a value for each variable, i.e. sales and net income is tabulated as follows in Table 1.

The result of multiple linear regression equation is as follows:

$$
Y=-488,835.061-0.48+0.773
$$

The constant value $(\alpha)$ is $-488,835.061$, This means that if there is no change in of sales and operating costs to net income dependent variable, it is still worth-488,835.061,

The regression coefficients for $\mathrm{X} 1$ have a negative value, meaning that there is no unidirectional relationship between sales (x1) and net income (Y). The regression coefficient of sales (X1) of -0.48 means that when sales increase, net income decreases. The regression coefficient for the variable X2 has a positive value, which means that there is a unidirectional relationship between operating costs (X2) and net income $(\mathrm{Y})$ where the regression coefficient operating costs (X2) is .773. This means that when the increased operating costs, net income will increase.

\section{Partial Test Results}

The partial effect of each independent variable is sales (X1) and operating costs (X2) on the net income (Y) as a dependent variable by using the criterion of hypothesis acceptance of $0.05(a=5 \%)$.

Based on these calculations, the significant value of $t$ in each variance will be compared with the results of the $\mathrm{t}$-table $\mathrm{n}=30$, with a significance level of $5 \%$, at the level of error $(\alpha=0.05)$ by using the 2 -sided test of degrees of freedom (nk) or $30-2=28$, and the t-table value $(28 ; 0.025)$ of 2.048. The significance value is $0.024<0.05$. This revealed that partially there is no effect $(\mathrm{t}$ value $<$ table $=$ $-2.393<2.048)$. Thus, it can be concluded that sales have no effect on net income. However, the results operating costs have a significant effect on net income.

Moreover, F-test (simultaneous test) has a significant influence on the dependent variable. Simultaneous testing is to examine the effect of two independent variables together on Table 3.

Table 1. Results of Multiple Linear Regression Analysis

\begin{tabular}{|c|c|c|c|c|c|c|}
\hline \multicolumn{7}{|c|}{ Coefficients } \\
\hline & \multirow{2}{*}{ Model } & \multicolumn{2}{|c|}{ Coefficients unstandardized } & \multirow{2}{*}{$\begin{array}{c}\text { standardized Coefficients } \\
\text { beta }\end{array}$} & \multirow{2}{*}{$\mathrm{T}$} & \multirow{2}{*}{ Sig. } \\
\hline & & B & Std. Error & & & \\
\hline \multirow{3}{*}{1} & (Constant) & $-488,835.061$ & $238,275.518$ & & -2.052 & .050 \\
\hline & Sales & -.048 & .020 & -.444 & -2.393 & .024 \\
\hline & Operating costs & .773 & .106 & 1.358 & 7.316 & .000 \\
\hline
\end{tabular}

Source: Data processed by SPSS, 2019.

Table 2. Partial Test Results ( $\mathrm{t}$ test)

\begin{tabular}{|c|c|c|c|c|c|}
\hline Variable & $\alpha$ & Sig & t-table & t-stat. & Verification \\
\hline Sales & 0.05 & 0.24 & 2.048 & -2.393 & Sales have no effect on net income \\
\hline Operating costs & 0.05 & 0.000 & 2.048 & 7.316 & Operating costs have a significant effect on net income \\
\hline
\end{tabular}

Table 3. Simultaneous Test (F-test)

\begin{tabular}{|c|c|c|c|c|c|c|}
\hline \multicolumn{2}{|c|}{ Model } & Sum of Squares & df & mean Square & F & Sig. \\
\hline \multirow{3}{*}{1} & Regression & $204,547,584,100,000.000$ & 2 & $102,273,792,000,000.000$ & 122.616 & $.000 \mathrm{~b}$ \\
\cline { 2 - 7 } & Residual & $22,520,652,110,000.000$ & 27 & $834,098,226,300.000$ & & \\
\cline { 2 - 6 } & Total & $227,068,236,200,000.000$ & 29 & & \\
\hline \multicolumn{2}{|l}{ a. Dependent Variable: Net Income (Y) } \\
\hline \multicolumn{2}{|l}{ b. Predictors: (Constant) Operating Costs (X2), Sales (X1) } \\
\hline
\end{tabular}


Table 4. Coefficient of Determination

\begin{tabular}{|c|c|c|c|c|}
\hline Model & $\mathrm{R}$ & $\mathrm{R}$ Square & Adjusted R Square & Std. Error of the Estimate \\
\hline 1 & $.949 \mathrm{a}$ & .901 & .894 & $913,166.88114$ \\
\hline a. Predictors: (Constant), Operation costs, Sales \\
\hline
\end{tabular}

The results showed that the variables of sales and operating costs have simultaneous effect on net income, indicated by the value of F-stat. of 122.616 and F-table with $5 \%$ significant value and DF1 and DF2 = $2=27$, and with F-table is $\mathrm{F}(2 ; 27)=3.35$. By comparing $\mathrm{F}_{\text {-stat. }}$ and $F_{\text {table }}(122.616>3.35)$, and significant value of $0.000>0.05$, it means that the H3 is accepted. It can be concluded that the sales and operating costs simultaneously affect the net profit.

Further test was conducted to analyze the coefficient of determination (R2). The coefficient of determination used to determine how much the ability of independent variables affects the dependent variables was tested using SPSS 23 and is shown in Table 4.

The coefficient is 0.949 , the coefficient of determination (R2) obtained was 0.901. It means that there is influence between the variables of sales and operating costs to net profit of $90.1 \%$. Meanwhile, the influence of $9.9 \%$ is by other variables outside of the variables examined. The finding is in line with Susilawati \& Mulyana [13] showing that sales and operating costs simultaneously affect net income. Ferliyanti [15] stated that sales have an influence on net income. Similarly, Akbar [16] stated that sales affect net income. The results showed that operating costs have an influence on the company's net profit. In this research shows the results that the operating costs partially influence on net profit in the company's award-winning of LPPOM 2019 MUI in the Indonesia Stock Exchange. This finding is in in line with Hidayanti et al. [17] and Hamzah et al. [18] showing that operational costs affect net profit. In addition, Susilawati \& Mulyana [13] also stated that operational costs had a significant effect on net income.

\section{Conclusion}

The partial testing results showed that sales had no effect on net income in companies that won the LPPOM 2019 MUI halal award listed on the Indonesia Stock Exchange. Meanwhile, operational costs have a significant effect on net income for companies that have won the halal award for LPPOM 2019 MUI which are listed on the Indonesia Stock Exchange. Meanwhile, the research results shown in this study show that Sales and operations simultaneously have a significant effect on net income in companies that have won the halal award for LPPOM 2019 MUI listed on the Indonesia Stock Exchange. However, the results revealed no close relationship between sales volume and an increase in the company's net income. Theoretical contribution to highlight the effects of financial performance in terms of sales and operational cost on net income in halal manufacturer. Practical implication is encouragement for management to improve sales performance of halal product to increase the financial performance of halal product manufacturing companies of net income.

\section{REFERENCES}

[1] Asyarie M. Islam, etos kerja \& pemberdayaan ekonomi umat. Yogyakarta: Lesfi, 1997.

[2] Adisasmito W. Analisis Kebijakan Nasional MUI dan BPOM dalam Labeling Obat dan Makanan. Bogor: Fakultas Kesehatan Masyarakat Universitas Indonesia, 2008.

[3] Sumarwan U. Perilaku konsumen: Teori dan penerapannya dalam pemasaran. Bogor: Ghalia Indonesia, 2011.

[4] Djamalu N. Pengaruh biaya produksi terhadap laba bersih pada perusahaan manufaktur yang terdaftar di Bursa Efek Indonesia periode 2010-2012. Undergraduate thesis, Universitas Negeri Gorontalo, 2013.

[5] A. Nurwulandari, I.M. Adnyana, Hasanudin, "Did inter-regional trade agreements bring mutual benefits? An empirical scheme of Indonesian commodity exports in Asean-China Free Trade Area,” Int. J. Financial Res., vol. 10, no. 6, pp. 241-249, 2019.

[6] Suranto E. R. Pengaruh Biaya Produksi Terhadap Penjualan Dan Laba Operasi Pada Perusahaan Manufaktur, Undergraduate, STIE Ekuitas, 2015.

[7] Hasanudin, A. Nurwulandari, I.M. Adnyana, N. Loviana, "The effect of ownership and financial performance on firvalue of oil and gas mining companies in Indonesia,” Int. J. Energy Econ. Policy, vol. 10, no. 5, pp. 103-109, 2020.

[8] Hery S. E. Akuntansi Keuangan Menengah. Jakarta: Gramedia Widiasarana Indonesia, 2021.

[9] Butar S. B. Board of commisioners composition, governance committee, and stock price synchronicity. Jurnal Akuntansi Dan Keuangan, vol. 21, no. 1, pp. 1-11, 2019.

[10] Reza M, Ullah S. Financial Reporting Quality of the Manufacturing Firms Listed in Indonesian Stock Exchange. Arthatama. vol. 3, no. 1, pp. 37-54, 2019.

[11] I.M. Adnyana, Hasanudin, A. Nurwulandari, "Empirical examination of intersectoral linkages between tourism and regional economy by using the social accounting matrix," Int. J. Econ. Bus. Adm, vol. 8, no. 1, pp. 425-432, 2020. 
[12] Murhadi W. R. Analisis Laporan Keuangan: Proyeksi dan Valuasi Saham. Jakarta: Salemba Empat, 2013.

[13] Susilawati E., Mulyana A. Pengaruh Penjualan dan Biaya Operasional terhadap Laba Bersih pada PT Indocement Tunggal Prakarsa (Persero) Tbk Periode Tahun 2010-2017. Organum: Jurnal Saintifik Manajemen dan Akuntansi, vol. 1, no. 2, pp. 74-87, 2018.

[14] Hernalisa, Pengaruh penjualan usaha dan beban operasional terhadap laba bersih pada perusahaan dagang PT. Bintang Central Imada. Final project, department of accounting, Academy of Accounting Permata Harapan Batam, 2017.

[15] Ferliyanti H. Pengaruh Biaya Produksi, Biaya Operasional, Dan Penjualan Terhadap Laba Bersih Pada Perusahaan Manufaktur Yang Terdaftar Di Bursa Efek Indonesia Tahun 2012-2016. Jurnal Akrab Juara, vol. 4, no. 1, pp. 52-62, 2019.
[16]Akbar A. S. Pengaruh Penjualan Dan Biaya Produksi Terhadap Laba Bersih (survei Pada Perusahaan Manufaktur Sektor Aneka Industri Sub Sektor Otomotif dan Komponen Yang terdaftar di Bursa Efek Indonesia (BEI) Tahun 2011-2016). Diploma Thesis, Universitas Komputer Indonesia, 2017.

[17] Hidayanti F., Yahdi M., Paramita R. W. D. Pengaruh Volume Penjualan dan Biaya Operasional Terhadap Laba Bersih Perusahaan (Studi Empiris Pada Perusahaan Manufaktur Sub Sektor Makanan dan Minuman yang Terdaftar di Bursa Efek Indonesia Tahun 2012-2016). Counting: Journal of Accounting , vol. 1, no.3, pp.88-99., 2019

[18] Ibnu Nur Hamzah, Firmansyah, Andi M. Alfian Parewangi , "Minimum Wages, Relative Wages, and Productivity: An Empirical Analysis on Indonesia Food and Beverage Industry," Universal Journal of Accounting and Finance, vol. 9. no. 1, pp. 33-43, 2021. DOI: 10.13189/ujaf.2021.090104 